Diabetologia 11, 501-507 (1975)

(c) by Springer-Verlag 1975

\title{
Effect of Methylxanthines on Alloxan Inhibition of Insulin Release*
}

\author{
P. E. Lacy, M. L. McDaniel, C. J. Fink and C. Roth \\ Dept. of Pathology, Washington Univ. School of Medicine, St. Louis, Missouri, USA \\ Received: March 18, 1975, and in revised form: July 23, 1975
}

\begin{abstract}
Summary. Isolated rat islets were maintained in vitro in a perifusion system, exposed to alloxan $(20 \mathrm{mg} / 100 \mathrm{ml})$ for 5 minutes in the presence of agents which affect cAMP metabolism and subsequently stimulated with glucose. The rate of insulin secretion was monitored throughout the period of perifusion. Exposure to alloxan alone produces complete inhibition of glucose-induced insulin release [18] whereas concomitant exposure to caffeine and theophylline for this brief interval provided almost complete protection of the islets from the inhibitory action of alloxan. Glucagon, cAMP
\end{abstract}

and DBcAMP did not protect the islets from alloxan. Pre-treatment of the islets with either theophylline or glucagon and DBcAMP did not provide protection. These findings indicate that the protective action of theophylline and caffeine against alloxan is unrelated to the effect of these agents on cAMP metabolism in the beta cell.

Key words: Isolated rat islets, in vitro insulin release, alloxan, theophylline, caffeine, cAMP, glucagon.
The development of a simple perifusion system has made it feasible to accomplish studies on the rate and pattern of insulin secretion of isolated rat islets maintained in vitro following stimulation with various insulin secretagogues $[10,11]$. Studies with this perifusion system demonstrated that exposure of isolated rat islets to alloxan for five minutes would inhibit subsequent glucose-induced insulin secretion [18]. The concurrent presence of a high concentration of either D-glucose, D-mannose, or 3-0-methyl-D-glucose with alloxan during this brief exposure interval provided almost complete protection of the B-cells from the inhibitory effect of alloxan on glucose-induced insulin release [17]. These same hexoses had been reported previously to block the diabetogenic action of alloxan in rats when administered prior to the injection of alloxan in vivo $[1,4,15,22]$. This in vitro perifusion system now makes it feasible to obtain quantitative information on the protective action of other agents against alloxan and to determine whether alloxan may prove to be a useful probe in studying the mechanism of induction of glucose-induced insulin release. The purpose of the present study was to determine the protective action against alloxan of agents which affect cAMP metabolism in the B-cell using the in vitro perifusion system.

* This research was supported in part by NIH grants AM03373 and AM06181

\section{Materials and Methods}

\section{Perifusion of Isolated Islets}

Islets were isolated from the pancreas of male Wistar rats (200-300 grams) using the collagenase technique described previously [10.12]. The perifusion system utilized was the same as employed in the previous studies on alloxan-inhibition of insulin secretion in vitro [17]. In this procedure, 100 islets were placed on the surface of a millipore filter $(5 \mu)$ in the perifusion chamber by means of a siliconized transfer pipette. Two chambers were used in each experiment and were perfused simultaneously - one serving as the control and the other as the experimental chamber. The chambers were maintained at $37^{\circ} \mathrm{C}$ in a water bath and were perfused at a flow rate of $0.7-0.8$ $\mathrm{ml} / \mathrm{min}$. The perifusate was collected in graduated tubes at 1 or 5 minute intervals during each experiment, the volumes were recorded, and $0.1 \mathrm{ml}$ aliquots were removed for insulin assay. The insulin content of the aliquots was determined by the radioimmunoassay procedure of Wright et al. [21] using crystalline pork insulin as the standard and ${ }^{125} \mathrm{I}$ labelled pork insulin (Cambridge Nuclear Radio Pharmaceutical Co.) as the tracer. The rate of insulin secretion was expressed as $\mu \mathrm{U}$ of insulin/islet/min.

The perifusion medium was composed of a modified Krebs-Ringer bicarbonate medium containing $115 \mathrm{mM} \mathrm{NACl}, 5 \mathrm{mM} \mathrm{KCl}, 2.5 \mathrm{mM} \mathrm{CaCl}_{2}, 24 \mathrm{mM}$ $\mathrm{NaHCO}_{3}, 1 \mathrm{mM} \mathrm{MgCl}$ and $0.5 \%$ albumin, (bovine 
plasma albumin, Armour Pharmaceutical Company, Chicago), and as required, alloxan monohydrate, $3^{\prime} 5^{\prime}$ cyclic adenosine monophosphate (cAMP), $\mathrm{n}^{6}-\mathrm{O}^{2}-$ dibutyryl 3' 5' cyclic adenosine monophosphate (DBcAMP), caffeine (Sigma Chemical Co.), D-glucose (Dextrose, National Bureau of Standrads, Washington, D. C.), theophylline ( $\mathrm{K}$ and $\mathrm{K}$ Laboratories, Plainview, N. J.), and glucagon Eli Lilly and Co.). The medium was equilibrated and maintained at $\mathrm{pH} 7.4$ with $95 \% \mathrm{O}_{2}$ and $5 \% \mathrm{CO}_{2}$.

\section{Exposure to Alloxan}

Since alloxan decomposes rapidly at $37^{\circ} \mathrm{C}$, previously warmed and gassed perifusion medium was added to alloxan monohydrate immediately prior to perifusion of the islets to yield a final concentration of $20 \mathrm{mg} / 100 \mathrm{ml}$. The islets in the experimental chamber were perifused with medium containing glucose $(1.0$ $\mathrm{mg} / \mathrm{ml}$ ) for 45 minutes and then the chamber was perfused with the medium containing alloxan and the agent to be tested for 5 minutes. After this 5 minute exposure period, the chambers were perfused with glucose $(5.0 \mathrm{mg} / \mathrm{ml})$ for a period of 60 minutes. The control chambers were perfused in a similar manner except that during the 5 minute exposure period the islets were perifused with medium containing only the agent to be tested. The amount of insulin released from the chambers was calculated for the pre-exposure, exposure, and post-exposure intervals and expressed as either $\mathrm{mU}$ of insulin/100 islets/ 60 minutes or $\mathrm{mU}$ of insulin $/ 100$ islets $/ 5$ minutes.

\section{Alloxan Assay}

Each of the agents used for possible protective action against alloxan inhibition of insulin secretion was studied for an effect of the decay curve of alloxan. The rate of decomposition of alloxan alone and in the presence of each test agent was determined at room temperature by measurement of changes in optical density at fixed wavelengths over the absorption spectrum (240-275 $\mathrm{m} \mu$ ) using a Zeiss spectrometer. A range of wavelengths was used in determining the effect of test agents on the half-life of alloxan in order to minimize the interfering absorption spectrum of some of these agents. A stock solution of alloxan (50 $\mathrm{mM}$ ) was prepared in $10^{-3} \mathrm{~N} \mathrm{HCl}$ immediately before use and aliquots were removed for incubation in Krebs-Ringer perifusion media without albumin, $\mathrm{pH}$ 7.4 , and in Tris buffer $(100 \mathrm{mM}), \mathrm{pH} 7.4$. In addition, a Carey spectrometer was used to scan the absorption spectrum of alloxan (220-300 $\mathrm{m} \mu)$ initially and after its decomposition both in the absence and presence of each agent to be tested.
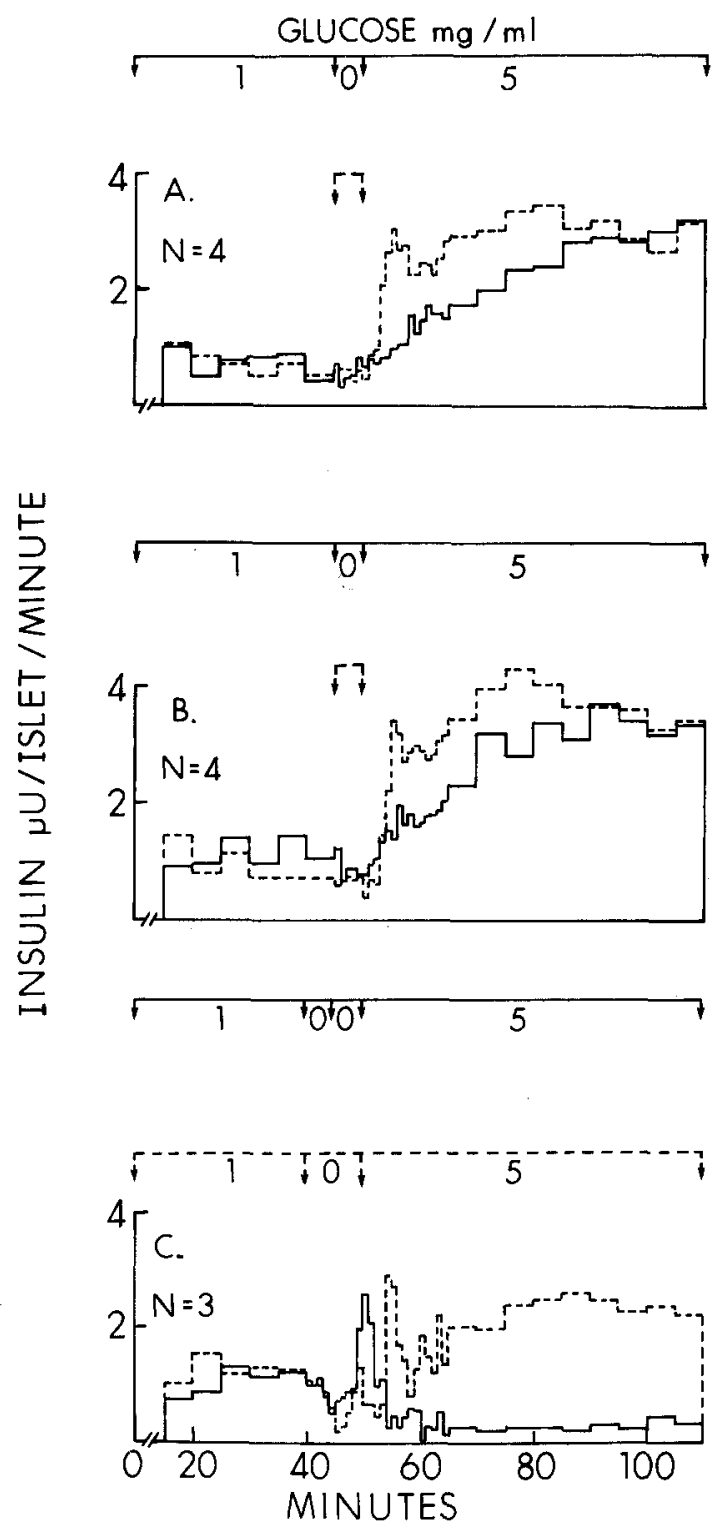

Fig. 1 a. The experimental chambers (solid line) were exposed to alloxan $(20 \mathrm{mg} / 100 \mathrm{ml})$ and theophylline $(10 \mathrm{mM})$ for $5 \mathrm{minu}-$ tes $(\downarrow \checkmark)$ and the control chambers (broken line) were exposed to theophylline $(10 \mathrm{mM})$ during the 5 minute interval $\left(5^{--} \downarrow\right)$. In this figure and subsequent figures unless indicated, all chambers were perfused with glucose $(1 \mathrm{mg} / \mathrm{ml})$ for 45 minutes, a glucose-free medium during the 5 minute pulse, and followed by glucose $(5$ $\mathrm{mg} / \mathrm{ml}$ ) for 60 minutes

Fig. 1 b. The experimental chambers (solid line) were exposed to alloxan $(20 \mathrm{mg} / 100 \mathrm{ml})$ and caffeine for 5 minutes $(\downarrow \neg)$ and the control chambers (broken line) were exposed to caffeine $(10 \mathrm{mM})$ during the 5 minute interval $\left(\downarrow^{-} \downarrow\right)$

Fig. $1 \mathrm{c}$. The experimental chambers (solid line) were perfused with theophylline $(10 \mathrm{mM})$ and glucose $(1 \mathrm{mg} / \mathrm{ml})$ for 40 minutes, a glucose-free medium for 5 minutes, and alloxan $(20 \mathrm{mg} / 100 \mathrm{ml})$ for 5 minutes $(\downarrow \downarrow \downarrow)$ ). The control chambers (broken line) were perfused with theophylline $(10 \mathrm{mM})$ and glucose $(1 \mathrm{mg} / \mathrm{ml})$ for 40 minutes followed by a 10 minute interval $\left(\left\ulcorner^{--} \downarrow\right)\right.$ in a glucose-free medium 


\section{Results}

\section{Effect of Theophylline and Caffeine}

In previous studies, we found that in vitro exposure of the islets to alloxan $(20 \mathrm{mg} / 100 \mathrm{ml})$ for 5 minutes would inhibit completely subsequent glucose-induced insulin release but did not affect the basal release of insulin from the islets $[17,18]$. Exposure of the islets to lower concentrations of alloxan (5 and 10 $\mathrm{mg} / 100 \mathrm{ml}$ ) produced partial inhibition of glucose-induced insulin release, whereas a higher concentration $(40 \mathrm{mg} / 100 \mathrm{ml})$ not only inhibited glucose-induced release but also decreased the basal secretion rate. Since alloxan $(20 \mathrm{mg} / 100 \mathrm{ml})$ completely inhibited glucose-induced insulin release without affecting ba- sal secretion, this concentration of alloxan was used in the present study.

A biphasic pattern of glucose-induced insulin release occurred following exposure of the islets to either theophylline $(10 \mathrm{mM})$ or caffeine $(10 \mathrm{mM})$ for 5 minutes in the absence of alloxan (Fig. 1). In the experimental chambers, exposure of the islets to either theophylline or caffeine in the presence of alloxan for 5 minutes resulted in a gradually increasing rate of secretion with an absence of the first phase of release. The rate of secretion in the experimental chambers approached the control levels approximately 30-35 minutes after exposure to alloxan in the presence of either theophylline or caffeine. The total amount of glucose-induced insulin release following exposure to alloxan in the presence of theophylline was

Table 1. Protective effect of certain agents on alloxan inhibition of glucose-induced insulin secretion Insulin Secretion

\begin{tabular}{|c|c|c|c|c|c|}
\hline \multirow{2}{*}{$\begin{array}{l}\text { Glucose } 1 \mathrm{mg} / \mathrm{ml}: 45 \mathrm{~min} \\
\mathrm{mU} / 100 \text { islets } / 60 \mathrm{~min}\end{array}$} & \multicolumn{3}{|c|}{ Glucose $0 \mathrm{mg} / \mathrm{ml}: 5 \mathrm{~min}$} & \multirow{2}{*}{$\begin{array}{l}\text { Glucose } 5 \mathrm{mg} / \mathrm{ml} \text { : } \\
60 \mathrm{~min} \\
\mathrm{mU} / 100 \\
\text { islets } / 60 \mathrm{~min}\end{array}$} & \multirow{2}{*}{$\begin{array}{l}\text { Percen } \\
\text { pro- } \\
\text { tection }\end{array}$} \\
\hline & \multicolumn{2}{|c|}{$\begin{array}{l}\text { Alloxan } \\
20 \mathrm{mg} / 100 \mathrm{ml} \text { Protective Agent }\end{array}$} & $\begin{array}{l}\mathrm{mU} / 100 \\
\text { islets/5 min }\end{array}$ & & \\
\hline $4.49 \pm 0.67^{\mathrm{a}}(4)^{\mathrm{b}}$ & + & Theophylline $10 \mathrm{mM}$ & $0.29 \pm 0.05^{\mathrm{a}}$ & $13.32 \pm 0.72^{\mathrm{a}}$ & $70.6^{\mathrm{d}}$ \\
\hline $4.51 \pm 1.06(4)$ & - & Theophylline $10 \mathrm{mM}$ & $0.31 \pm 0.12$ & $17.02 \pm 0.68$ & \\
\hline Insig. & & & Insig. & $\mathrm{P}<0.01$ & \\
\hline $6.69 \pm 1.12(4)$ & + & Caffeine $10 \mathrm{mM}$ & $0.46 \pm 0.07$ & $16.49 \pm 1.75$ & \\
\hline $5.83 \pm 1.62(4)$ & - & Caffeine $10 \mathrm{mM}$ & $0.35 \pm 0.09$ & $20.15 \pm 2.75$ & 68.4 \\
\hline Insig. & & & Insig. & Insig. & \\
\hline $3.61 \pm 0.62(4)$ & + & cAMP $5 \mathrm{mM}$ & $0.32 \pm 0.06$ & $3.52 \pm 0.62$ & \\
\hline $2.37 \pm 1.10(4)$ & - & cAMP $5 \mathrm{mM}$ & $0.09 \pm 0.06$ & $17.17 \pm 1.37$ & 0 \\
\hline Insig. & & & $\mathrm{P}<0.05$ & $\mathbf{P}<0.001$ & \\
\hline $4.66 \pm 1.76$ & + & DBcAMP $5 \mathrm{mM}$ & $0.31 \pm 0.13$ & $8.17 \pm 2.94$ & \\
\hline $4.97 \pm 2.04(4)$ & - & DBcAMP $5 \mathrm{mM}$ & $0.41 \pm 0.21$ & $35.22 \pm 3.21$ & 11.6 \\
\hline Insig. & & & Insig. & $P<0.001$ & \\
\hline $4.76 \pm 1.98(4)$ & + & Glucagon $10 \mu \mathrm{g} / \mathrm{ml}$ & $0.84 \pm 0.09$ & $4.40 \pm 1.34$ & \\
\hline $4.79 \pm 1.60(4)$ & - & Glucagon $10 \mu \mathrm{g} / \mathrm{ml}$ & $0.36 \pm 0.12$ & $24.15 \pm 4.22$ & 0 \\
\hline Insig. & & & $\mathrm{P}<0.025$ & $P<0.005$ & \\
\hline $4.62 \pm 1.82(3)$ & - & DBcAMP $5 \mathrm{mM}$ & $0.27 \pm 0.10$ & $36.82 \pm 5.83$ & \\
\hline $2.33 \pm 0.38(3)$ & - & - & $0.17 \pm 0.10$ & $27.30 \pm 3.50$ & - \\
\hline \multicolumn{6}{|c|}{${ }^{c}$ Theophylline $10 \mathrm{mM} 40 \mathrm{~min}$} \\
\hline $7.28 \pm 1.11(3)$ & + & - & $0.53 \pm 0.13$ & $2.35 \pm 0.97$ & \\
\hline $3.81 \pm 0.64(3)$ & - & - & $0.33 \pm 0.05$ & $12.38 \pm 2.47$ & 0 \\
\hline Insig. & & & Insig. & $P<0.025$ & \\
\hline \multicolumn{6}{|l|}{ DBCAMP 5 mM } \\
\hline \multicolumn{6}{|l|}{ Glucagon $10 \mu \mathrm{g} / \mathrm{ml}$} \\
\hline $5.82 \pm 1.24(4)$ & + & $\begin{array}{l}\text { DBcAMP } 5 \mathrm{mM} \\
\text { Glucagon } 10 \mathrm{ug} / \mathrm{ml}\end{array}$ & $0.38 \pm 0.09$ & $6.86 \pm 2.80$ & \\
\hline $7.54 \pm 1.17(4)$ & - & $\begin{array}{l}\text { DBcAMP } 5 \mathrm{mM} \\
\text { Glucagon } 10 \mathrm{\mu g} / \mathrm{ml}\end{array}$ & $0.25 \pm 0.05$ & $\begin{array}{l}21.04 \pm 3.48 \\
P<0.05\end{array}$ & 7.7 \\
\hline
\end{tabular}

a Standard error of the mean

b Number of experiments in parentheses

c The islets were perifused for 40 minutes with theophylline $(10 \mathrm{mM})$ and glucose $(1.0 \mathrm{mg} / \mathrm{ml})$ followed by perifusion for 5 minutes without theophylline or glucose, in order to be certain that theophylline would not be present during exposure of the islets to alloxan.

\footnotetext{
${ }^{d}$ Percent protection $=\frac{\text { (Rate stimulated release }- \text { basal rate [Exp.] }}{\text { (Rate stimulated release }- \text { basal rate }[\text { Control] }} \times 100$
} 
$13.32 \pm 0.72 \mathrm{mU} / 100$ islets in comparison with $17.02 \pm 0.68 \mathrm{mU} / 100$ islets in the control chambers $(\mathrm{P}<0.01)$ and in the presence of caffeine $16.49 \pm 1.75 \mathrm{mU} / 100$ islets with a release of $20.15 \pm 2.75 \mathrm{mU} / 100$ islets in the control chambers $(\mathrm{P}<0.3)$ (Table 1). The percent protection against alloxan toxicity provided by theophylline was $70.6 \%$ and caffeine provided $68.4 \%$. During the exposure period to alloxan, the rate of insulin release and the total amount of insulin released was not significantly different from the controls during this 5 minute interval.

Since theophylline produces a significant increase in the amount of cAMP in isolated islets [5, 15], studies were accomplished to determine whether pretreatment with theophylline would protect the islets from alloxan. In the experimental chambers, the islets were perifused with glucose $(1.0 \mathrm{mg} / \mathrm{ml})$ and theophylline $(10 \mathrm{mM})$ for 40 minutes, basal medium for 5 minutes, followed by exposure to alloxan $(20 \mathrm{mg} / 100 \mathrm{ml})$ for 5 minutes in the absence of theophylline with subsequent exposure to glucose $(5.0 \mathrm{mg} / \mathrm{ml})$ for 60 minutes. The perfusion with only basal medium for 5 minutes was accomplished in order to be certain that theophylline was eliminated completely from the perifusion system prior to exposure to alloxan. The control chambers were perfused in a similar manner with alloxan absent prior to glucose stimulation.

As shown in Fig. $1 \mathrm{c}$, pretreatment of the islets with theophylline did not provide protection against alloxan. The islets pretreated with theophylline and exposed to alloxan released $2.35 \pm 0.97 \mathrm{mU} / 100$ islets during the period of glucose stimulation as compared to $12.38 \pm 2.47 \mathrm{mU} / 100$ islets in the controls (Table 1). It is of interest that the rate of secretion in the islets exposed to alloxan increased during the exposure, reached a maximum 1 minute after exposure and decreased rapidly.

\section{Effect of cAMP, DBCAMP and Glucagon}

Exposure of the islets to cAMP (5 mM) in the presence of alloxan did not protect the islets from the action of alloxan on inhibition of subsequent glucoseinduced insulin release (Table 1). In the experimental chambers, the total insulin released in the pre-exposure interval was $3.61 \pm 0.62 \mathrm{mU} / 100$ islets as compared to $3.52 \pm 0.62 \mathrm{mU} / 100$ islets during glucose stimulation in the post-exposure interval. A burst of insulin release did occur during the 5 minute period of exposure to alloxan and CAMP which was significantly greater than the release from the control chambers during this interval $(\mathrm{P}<0.05)$ (Table 1). Dibutyryl

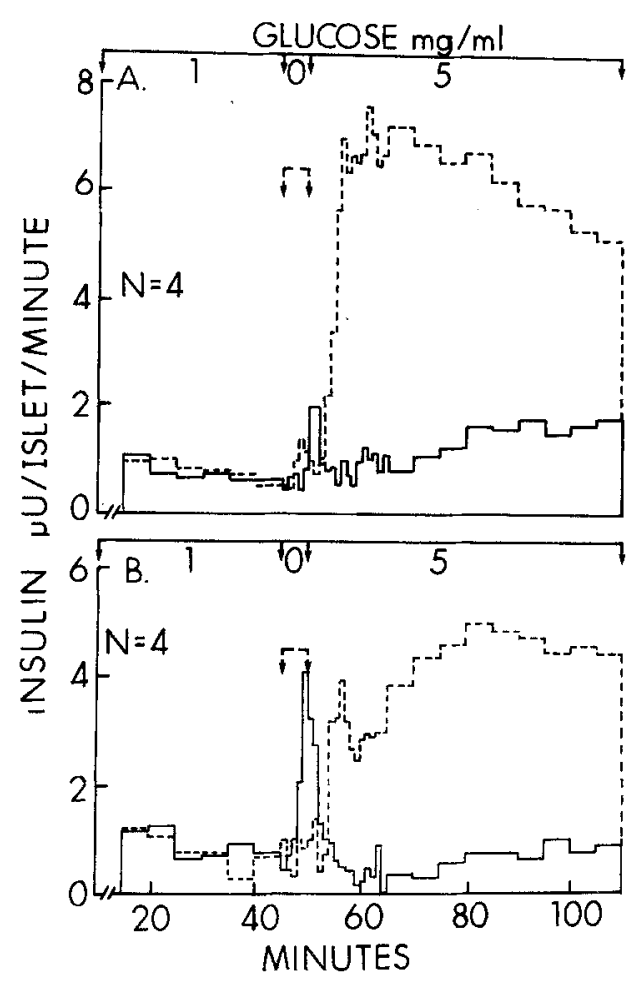

Fig. 2 a. The experimental chambers (solid line) were exposed to alloxan $(20 \mathrm{mg} / 100 \mathrm{ml})$ and DBcAMP $(5 \mathrm{mM})$ for 5 minutes $(\sqrt{ })$ and the control chambers (broken line) were exposed to DBcAMP $(5 \mathrm{mM})$ during the 5 minute interval $\left(\downarrow^{---} \downarrow\right)$

Fig. $2 \mathrm{~b}$. The experimental chambers (solid line) were exposed to alloxan $(20 \mathrm{mg} / 100 \mathrm{ml})$ and glucagon $(10 \mu \mathrm{g} / \mathrm{ml})$ for 5 minutes $(\downarrow \neg)$ and the control chambers were exposed to glucagon (10 $\mu \mathrm{g} / \mathrm{ml})$ during the 5 minute interval $\left(r^{-\cdots}\right)$

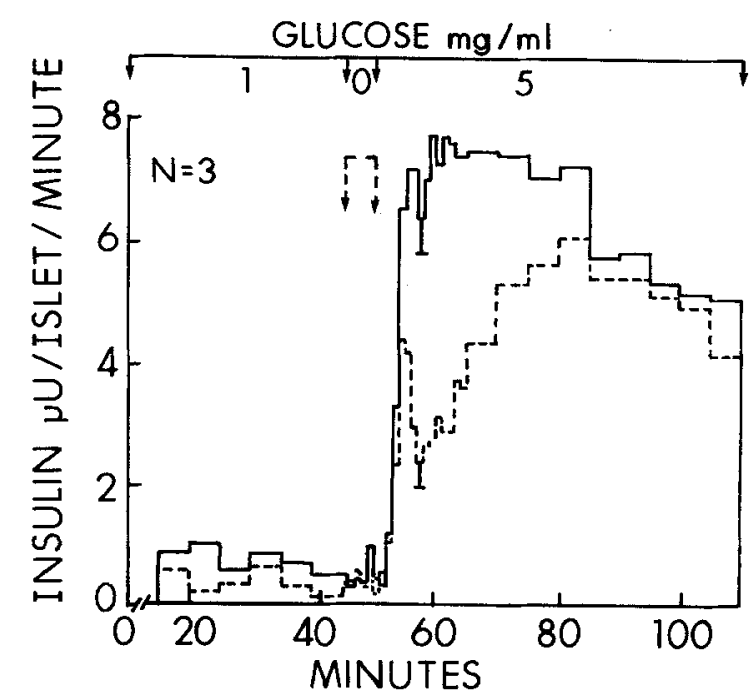

Fig. 3. The experimental chambers (solid line) were exposed to DBcAMP ( $5 \mathrm{mM}$ ) for 5 minutes $(\downarrow \downarrow)$ and the control chambers were exposed only to a glucose-free medium during the 5 minute interval $\left(i^{-\cdots}\right)$ 
cAMP ( $5 \mathrm{mM})$ did not protect the islets from alloxan (Table 1). An increase in the rate of insulin secretion was present for 2 minutes immediately after exposure to alloxan and DBcAMP (Fig. 2 a). A comparison of the rate and pattern of insulin release of control islets subjected to glucose stimulation and of islets exposed to DBcAMP alone for 5 minutes and then stimulated with glucose is shown in Fig. 3. Exposure of the islets to DBcAMP for 5 minutes resulted in the elimination of a distinct first phase of release with a blending of the two phases into one, as well as a significantly increased rate of insulin release during the first 30 minutes of glucose stimulation.

Glucagon $(10 \mu \mathrm{g} / \mathrm{ml})$ did not protect the islets against alloxan, as shown in Fig. 2 b. A marked spike of insulin release did occur during exposure to alloxan and glucagon $(10 \mu \mathrm{g} / \mathrm{ml})$, reaching a maximum rate during the last 1 minute interval of exposure. The total amount of insulin released during the 5 minute exposure to alloxan and glucagon was significantly greater than in control chambers (Table 1). Exposure to glucagon did not affect the normal biphasic pattern of release induced by glucose.

\section{Pretreatment with Glucagon and DBCAMP}

In the experiments on the effect of pretreatment of the islets with theophylline, it was possible that the accumulated cAMP in the islets was decreased during the five minute perfusion with basal medium prior to exposure to alloxan. In order to avoid this possibility, glucagon and DBcAMP were used to accumulate cAMP in the islets since neither of these agents provided protection when they were present with alloxan during the five minute exposure period. In the experimental chambers, the islets were perifused with glucagon $(10 \mu \mathrm{g} / \mathrm{ml})$ and DBcAMP $(5 \mathrm{mM})$ for 45 minutes as well as during the 5 minute exposure to alloxan. The control chambers were perfused in a similar manner with alloxan absent prior to stimulation with glucose.

Pretreatment with glucagon and DBcAMP did not provide protection against alloxan (Table 1). The islets pretreated with glucagon and DBcAMP and exposed to alloxan in the presence of these agents released $6.86 \pm 2.80 \mathrm{mU} / 100$ islets during the period of glucose stimulation as compared to $5.82 \pm 1.24$ $\mathrm{mU} / 100$ islets during the pretreatment interval. The pattern of insulin release in the control chambers resembled that obtained following exposure to DBcAMP for 5 minutes (Fig. $2 \mathrm{a}$ ), with a greater falloff in the rate during the last 30 minutes of glucose stimulation.

\section{Assay of Alloxan}

Since it was possible that the protective action of some of the agents tested could be due to a direct chemical reaction with alloxan, spectrophotometric studies were accomplished on the effect of these agents on the decay curve of alloxan in vitro. At room temperature, the average half-time for the decomposition of alloxan was 3.1 minutes. None of the agents used in this study had any effect on the rate of decomposition of alloxan. The agents were added to alloxan in molar ratios of $1: 1$ and $2: 1$.

A Carey spectrometer was used to scan the absorption spectrum $(220-300 \mathrm{~m} \mu)$ for alloxan initially and its decomposition pattern after 25 minutes of incubation. This same procedure was repeated for alloxan in the presence of the test agents which alone displayed stable spectrums. The observed absorption spectrum of alloxan in the presence of each agent initially, and after 25 minutes of incubation, corresponded precisely with that which would result from the addition of each spectrum obtained separately at these same time intervals. These findings indicated that the protective action of caffeine and theophylline was not due to a direct chemical reaction with alloxan.

\section{Discussion}

The present study indicates that theophylline and caffeine will also protect the perifused islets from alloxan (68.4-70.6\%). Since theophylline and caffeine inhibit cyclic nucleotide phosphodiesterase activity [3, 17] and also result in an increase in the amount of cAMP in isolated islets [5], it could be assumed that the mechanism of protection provided by these agents is through their effect on cAMP metabolism in the B-cells. The subsequent series of experiments performed in the present study does not support this assumption.

The findings which indicate that the protective action of theophylline and caffeine may not be due to their inhibition of phosphodiesterase activity and accumulation of cAMP in the B-cell are as follows: a) Exposure of the islets to cAMP in the presence of alloxan did not provide protection against alloxan. This lack of effect of cAMP could be due to the poor penetrability of this agent into the cells [8]. b) Dibutyryl cAMP, which penetrates the cell membrane easily and is resistant to catabolism by phosphodiesterase [2, $7,8]$ did not provide protection. Jarett and Smith [9] have shown that DBCAMP directly inhibits phosphodiesterase resulting in a marked increase in endogenous cAMP levels and that DBcAMP causes a far 
greater increase in cAMP levels in adipocytes than theophylline. These authors also demonstrated that less than $10 \%$ of the cAMP came from the breakdown of $D B C A M P$ and the rest was of endogenous origin. If DBcAMP has the same mode of action on the Bcell, then endogenous cAMP would continue to be produced and phosphodiesterase activity would be inhibited. Exposure of the perifused islets to only DBcAMP for five minutes produced an immediate, marked enhancement of the rate of glucose-induced insulin release (Fig. 3), indicating that the agent had penetrated the B-cell and was probably inhibiting phosphodiesterase activity with a resultant accumulation of endogenous cAMP in the B-cells. If DBcAMP inhibits phosphodiesterase in the islets, as occurs with theophylline and caffeine, then it would appear unlikely that theophylline and caffeine are providing protection against alloxan through their action on phosphodiesterase. c) Pretreatment of the islets with theophylline $(10 \mathrm{mM})$ and glucose $(1.0$ $\mathrm{mg} / \mathrm{ml}$ ) for 40 minutes prior to exposure to alloxan did not provide protection from alloxan. This period of pretreatment should have resulted in the accumulation of cAMP in the B-cell, yet protection from alloxan was not observed. d) Exposure of the islets to glucagon and alloxan did not protect the B-cells. e) Pretreatment of the islets with glucagon and DBcAMP for 45 minutes as well as during exposure to alloxan did not provide protection. Since these agents were present before and during exposure to alloxan, the accumulated cAMP in the islets would not be lost in contrast to a possible loss of CAMP in the pretreatment experiments with theophylline. f) None of the agents tested reacted chemically with alloxan as determined by the effect of the agents on the decay curve of alloxan. In view of these findings, it is suggested that the protective action of theophylline and caffeine against alloxan is unrelated to the effect of these agents on cAMP metabolism in the B-cell and that these agents do not react chemically with alloxan.

It is of interest that stimulation of insulin release occurred during the 5 minute period of exposure to alloxan when the agent being tested did not provide protection against alloxan. This was most evident when the islets were exposed to alloxan in the presence of glucagon or cAMP and following pretreatment with theophylline (Figs. 1c, 2 b and Table 1). Matschinsky (personal communication) has observed a similar direct effect of alloxan alone on insulin released by the perfused intact rat pancreas. In our previous perifusion studies, we did not observe this stimulatory action of alloxan. However, in these studies glucose $(1.0 \mathrm{mg} / \mathrm{ml})$ was present with the alloxan, whereas in the present studies glucose was absent during the 5 minute exposure.

The molecular basis for the protective action of certain agents against either the diabetogenic action of alloxan in vivo or the in vitro inhibition of glucose-induced insulin secretion by alloxan is unknown. The precise cellular site for this protective action is also unknown. However, certain evidence would suggest that the site may be the B-cell membrane. Orci et al. [13], using freeze-etch electron microscopy, have reported that exposure of isolated rat islets to alloxan causes a loss of membranous particles from the Bcell membrane. Dean and Matthews [6] have measured membrane potentials of B-cells in isolated mouse islets and reported that alloxan will cause depolarization of the B-cells. Recent studies indicate a definite stereospecificity for the protective action of glucose with the alpha anomer of D-glucose providing protection at lower concentration than the B-anomer against the diabetogenic effect of alloxan in rats [14]. In studies of toad fish islets, Watkins et al. [20] have suggested that alloxan may damage the B-cell membrane by acting on or near a glucose receptor or transport site involved with insulin release. It has been suggested that the protective effect of glucose may be the result of a conformational change in the beta cell membrane induced by glucose directly or by the transport or metabolism of glucose $[14,22]$. The demonstration in the present study of the protective action of theophylline and caffeine provides additional agents which can be used to attempt to elucidate the mechanism by which the B-cell is protected from alloxan and the precise site and molecular basis for the toxic action of alloxan on the B-cell. Studies are in progress on the transport of radioactive labelled alloxan and theophylline into isolated rat islets.

\section{References}

1. Bhattacharya, G.: Protection against alloxan diabetes by mannose and fructose. Sience 117, 230-231 (1953)

2. Blecher, M.: Biological effects and catabolic metabolism of $3^{\prime}$ $5^{\prime}$-cyclic nucleotides and derivatives in rat adipose tissue and liver. Metabolism 20, 63-77 (1971)

3. Butcher, R. W., Sutherland, E. W.: Adenosine $3^{\prime} 5^{\prime}$-phosphate in biologic materials. Purification and properties of cyclic $3^{\prime}$ 5 '-nucleotide phosphodiesterase and use of this enzyme to characterize adenosine $3^{\prime} 5^{\prime}$-phosphate in human urine. J. biol. Chem. 237, 1244-1250 (1962)

4. Carter, W. J., Younathan, E. S.: Studies on protection against the diabetogenic effect of alloxan by glucose. Proc. Soc. exp. Biol (N. Y.) 109, 611-612 (1962)

5. Cooper, R. H., Ashcroft, S. J. H., Randle, P. J.: Concentration of adenosine $3^{\prime}: 5^{\prime}$-cyclic monophosphate in mouse pancreatic islets measured by a protein-binding radioassay. Biochem. J. 134, 599-605 (1973) 
6. Dean, D. M., Matthews, E. K.: The bioelectrical properties of pancreatic islet cells: effect of diabetogenic agents. Diabetologia 8, 173-178 (1972)

7. Drummond, G. I., Powell, C. A.: Analogues of adenosine $3^{\prime}$ $5^{\prime}$-cyclic phosphate as activators of phosphorylase $b$ kinase and as substrates for cyclic $3^{\prime} 5^{\prime}$-nucleotide phosphodiesterase. Mol. Pharmacol. 6, 24-30 (1970)

8. Henion, W. F., Sutherland, E. W., Posternak, T.: Effects of derivatives of adenosine 3' 5'-phosphate on liver slices in intact animals. Biochim. biophys. Acta (Amst.) 148, 106-113 (1967)

9. Jarett, L., Smith. R. M.: Mode of action of $\mathrm{N}^{6}-\mathrm{O}^{2}$-dibutyryl cyclic $3^{\prime} 5^{\prime}$ AMP on fat cell metabolism. Diabetes 23, 29-40 (1974)

10. Lacy, P. E., Walker, M. M., Fink, C. J.: Perifusion of isolated rat islets in vitro: participation of the microtubular system in the biphasic release of insulin. Diabetes 21, 987-998 (1972)

11. Lacy, P. E., Klein, N. J., Fink, C. J.: Effect of cytochalasin B on the biphasic release of insulin in perifused rat islets. Endocrinology 92, 1458-1468 (1973)

12. Lacy, P. E., Kostianovsky, M.: Method for the isolation of intact islets of Langerhans from the rat pancreas. Diabetes 16, 35-39 (1967)

13. Orci, L., Amherdt, M., Stauffacher, W., Like, A. A., Rouiller, C., Renold, A. E.: Structural changes in membranes of beta cells exposed to alloxan and streptozotocin demonstrated by freeze-etching. Diabetes 21 (Suppl. 1), 326 (1972)

14. Rossini, A. A., Berger, M., Shadden, J., Cahill, G. F., Jr.: Beta cell protection to alloxan necrosis by anomers of D-glucose. Sience 183, 424 (1974)

15. Sams, D. J. and Montague, W.: The role of adenosine $3^{\prime}: 5^{\prime}-c y-$ clic monophosphate in the regulation of insulin release. Biochem. J. 129, 945-952 (1972)
16. Scheynius, A., Täljedal, I.-B.: On the mechanism of glucose protection against alloxan toxicity. Diabetologia 7, 252-255 (1971)

17. Sutherland, E. W., Rall, T. W.: Fractionation and characterization of a cyclic adenosine ribonucleotide formed by tissue particles. J. biol. Chem. 232, 1077-1091 (1958)

18. Tomita, T., Lacy, P. E., Matschinsky, F. M., McDaniel, M. L.: The effect of alloxan on insulin secretion in isolated rat islets perifused in vitro. Diabetes 23, 517-524 (1974)

19. Tomita, T., Lacy, P. E.: Interaction of alloxan and glucoseinduced insulin secretion of isolated rat islets perifused in vitro. Diabetes 21 (Suppl. 1), 326 (1972)

20. Watkins, D., Cooperstein, S. J., Lazarow, A.: Effect of alloxan on islet tissue permeability: protection and reversals by sugars. Amer. J. Physiol. 224, 718-722 (1973)

21. Wright, P. H., Makulu, D. R., Vichick, D., Sussmann, K. E.: Insulin immunoassay by back-titration; some characteristics of the technique and the insulin precipitant action of alcohol. Diabetes 20, 33-45 (1971)

22. Zawalich, W. S., Beidler, L. M.: Glucose and alloxan interactions in the pancreatic islets. Amer. J. Physiol. 224, 963-966 (1973)

P. E. Lacy, M. D.

Mallinckrodt Prof. and

Chairman

Dept. of Pathology

Washington Univ.

School of Medicine

St. Louis, Missouri 63110

USA 